\title{
SUXAMETHONIUM-INDUCED HYPERKALAEMIA IN PATIENTS WITH SEVERE INTRA-ABDOMINAL INFECTIONS
}

\author{
BrigitTe Kohlschütter, Helen BaUR and F. Roth
}

\begin{abstract}
SUMMARY
In nine patients, undergoing repeat operations because of severe intra-abdominal infection developing after major abdominal surgery, serum potassium concentrations were monitored during induction of anaesthesia. Four patients showed an increase of serum potassium ranging from 2.5 to $3.1 \mathrm{mmol} /$ litre above baseline values within 3-6 min after suxamethonium $100 \mathrm{mg}$ i.v. In five patients there was no change. The four patients demonstrating an increase had suffered from pyrexia and leucocytosis for at least 2 weeks. The other five had signs of infection for no more than 9 days. It is concluded that patients with signs of severe intra-abdominal infection lasting longer than 1 week represent an additional category susceptible to suxamethonium-induced hyperkalaemia. They should receive only non-depolarizing muscle relaxants. When the use of suxamethonium is unavoidable, the injection of a non-depolarizing muscle relaxant before the administration of suxamethonium is recommended.
\end{abstract}

A dangerous increase in serum potassium concentrations after the administration of suxamethonium has been reported in an increasing number of clinical conditions including burns (Tolmie, Joyce and Mitchell, 1967), massive muscle trauma (Birch et al., 1969; Mazze, Escue and Houston, 1969), tetanus (Roth and Wüthrich, 1969), neuromuscular disease (Cooperman, 1970) and uraemia (Roth and Wüthrich, 1969; Walton and Farman, 1973). Several of the reported patients suffered cardiac arrest within $5 \mathrm{~min}$ after the administration of suxamethonium. We observed cardiac and circulatory arrest in a seriously ill patient with a subphrenic abscess 3 min after administration of suxamethonium during induction of anaesthesia. After external cardiac massage and the i.v. injection of sodium bicarbonate, the circulation was restored within $3 \mathrm{~min}$ and no brain damage occurred. The course of events was similar to the incidents reported in suxamethonium-induced hyperkalaemia. Therefore we investigated the effect of intra-abdominal infection on the susceptibility to suxamethonium-induced hyperkalaemia.

\section{METHODS}

In a period of 15 months all patients presented to us with major complications following abdominal sur-

BRIGITTE KOHLSCHÜTTER, DR MED.; HELEN BAUR, DR MED.; FRIEDRICH ROTH, DR MED.; Intensive Care Unit, Department of Anaesthesiology, University Hospital, Berne, Switzerland.

Address for correspondence: Dr F. Roth, Abt. für Reanimation und Intensivbehandlung, Inselspital, CH-3010 Berne/Switzerland. gery, such as leaking intestinal anastomosis or intraabdominal abscess, were studied. All were receiving parenteral nutrition to meet caloric needs and were to undergo a further laparotomy under general anaesthesia. Anaesthesia was induced in nine patients with cyclohexylamine (ketamine) $2-3 \mathrm{mg} / \mathrm{kg}$ body weight i.v.; in two patients with droperidol $15 \mathrm{mg}$ and fentanyl $0.3 \mathrm{mg}$ i.v. Oxygen $100 \%$ was administered by face mask. Two venous blood samples were taken for the baseline determination of potassium concentrations. Pancuronium $2 \mathrm{mg}$ was then injected i.v. in order to control a potentially hazardous increase in serum potassium concentrations (Weintraub, Heisterkamp and Cooperman, 1969). Three to five minutes later, suxamethonium $100 \mathrm{mg}$ was injected, the trachea was intubated and anaesthesia was maintained with a mixture of $70 \%$ nitrous oxide in oxygen. Blood samples were taken from a subclavian catheter every minute for the first $10 \mathrm{~min}$ and 20 and $30 \mathrm{~min}$ after the injection of suxamethonium.

\section{CASE REPORTS}

(See also table I and fig. 1.)

Case No. 1

A 43-year-old man had undergone repair of a hiatus hernia in another hospital and developed a pleural empyema necessitating drainage. Two weeks later a second laparotomy was performed for massive bleeding from duodenal ulcers. A partial gastrectomy with gastro-jejunostomy was performed. Two days later he was transferred to our hospital because of septic shock. Leakage of the duodenal stump was 
TABLE I. Relationship of clinical data and the serum potassium concentration. The patients with a significant increase of serum potassium all had pyrexia and leucocytosis for at least 2 weeks. The patients without a significant increase in potassium had these signs of infection for less than 9 days

\begin{tabular}{|c|c|c|c|}
\hline Patient no. & Diagnosis & $\begin{array}{l}\text { Duration of } \\
\text { pyrexia and } \\
\text { leucocytosis } \\
\text { (days) }\end{array}$ & $\begin{array}{c}\text { Increase of serum } \\
\text { potassium } \\
>1.5 \mathrm{mmol} / \text { litre } \\
\text { above baseline } \\
\text { values }\end{array}$ \\
\hline 1 & subphrenic abscess & 35 & $\begin{array}{l}\text { cardiocirculatory } \\
\text { collapse }\end{array}$ \\
\hline 1 & $\begin{array}{l}\text { leakage of duodenal stump; } \\
\text { bleeding from gastroduodenal } \\
\text { artery }\end{array}$ & 42 & yes \\
\hline 2 & $\begin{array}{l}\text { abscess in pouch of Douglas; } \\
\text { necrosis of the uterus }\end{array}$ & 14 & yes \\
\hline 3 & psoas abscess & 24 & yes \\
\hline 3 & psoas abscess & 51 & yes \\
\hline 3 & psoas abscess & 71 & yes \\
\hline 4 & intra-abdominal abscess & 24 & yes \\
\hline 5 & leakage of anastomosis & 4 & no \\
\hline 6 & $\begin{array}{l}\text { leakage of gastro-duodenostomy; } \\
\text { leakage of choledocho- } \\
\text { jejunostomy }\end{array}$ & 4 & no \\
\hline 7 & $\begin{array}{l}\text { distension of caecum; local } \\
\text { peritonitis }\end{array}$ & 5 & no \\
\hline 8 & $\begin{array}{l}\text { subphrenic abscess; abscess in } \\
\text { pouch of Douglas }\end{array}$ & 9 & no \\
\hline 9 & small bowel fistula & 一 & no \\
\hline
\end{tabular}

found at operation. Pyrexia persisted even after adequate drainage and a third laparotomy was performed, 3 weeks after admission, because of a suspected abscess. During induction of anaesthesia, $3 \mathrm{~min}$ after injection of suxamethonium, the patient

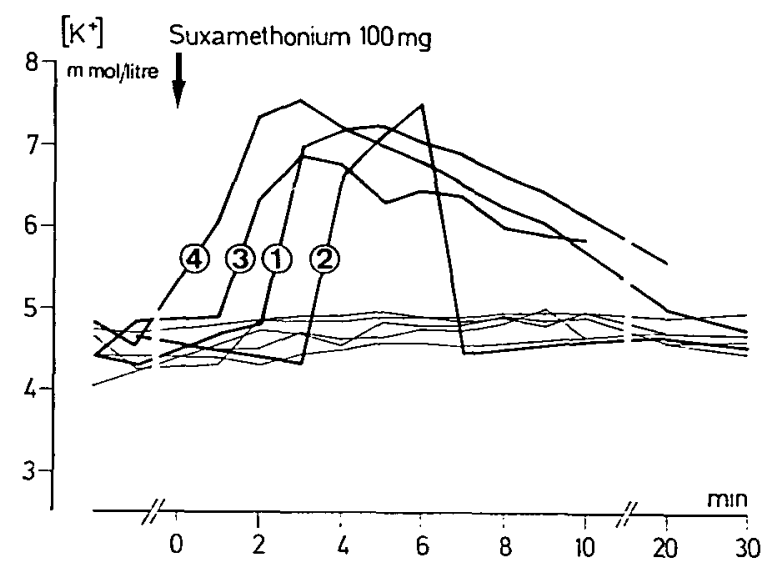

FIG. 1. Patients 1 to 4 showed a striking increase in their serum potassium concentrations within the first few minutes after the administration of suxamethonium, while patients 5 to 9 remained within the normal range. suffered a cardiocirculatory arrest and was resuscitated. A sub-phrenic abscess was found. Seven days later massive gastrointestinal bleeding necessitated a fourth laparotomy. On this occasion the serum potassium concentration was monitored during induction of anaesthesia. There was an increase from 4.30 to a maximum of $7.25 \mathrm{mmol} /$ litre $5 \mathrm{~min}$ after the injection of suxamethonium $100 \mathrm{mg}$. A ruptured gastroduodenal artery was ligated. The postoperative course was complicated by uncontrollable infection, respiratory and renal insufficiency, impaired wound healing and Candida albicans septicaemia. The patient died 3 months after admission.

\section{Case No. 2}

A 21-year-old woman was admitted from another hospital 9 days after Caesarean section. On admission her skin was grey-blue in colour, her temperature was $39^{\circ} \mathrm{C}$, and the leucocyte count was $26000 / \mathrm{mm}^{3}$. Five hundred millilitre of pus were drained from a necrotic abdominal wound. During the following days pyrexia persisted and there was purulent discharge from the wound and the vagina. Pyometra or necrosis of the uterus was suspected. Eight days after admission laparotomy was performed. During 
induction of anaesthesia the serum potassium concentration increased from 4.65 to a maximum of $7.50 \mathrm{mmol} /$ litre $6 \mathrm{~min}$ after injection of suxamethonium $100 \mathrm{mg}$. A partially necrotic uterus and a large abscess in the pouch of Douglas were found. Hysterectomy with adequate drainage was performed. The patient recovered.

\section{Case No. 3 (fig. 2)}

A 45-year-old man was admitted because of acute gastrointestinal bleeding, from duodenal ulcers, and pleural empyema. The bleeding was treated conservatively, and the empyema was drained, but pyrexia persisted. Four days later a psoas abscess was

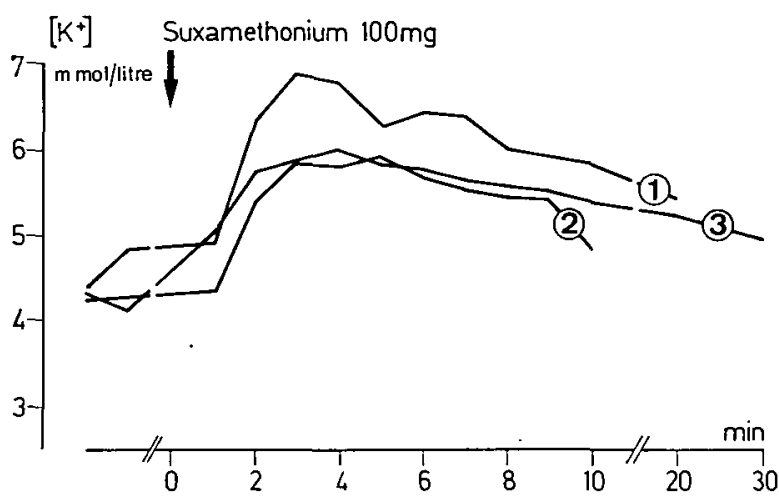

FIG. 2. Patient 3. An increase of serum potassium after the administration of suxamethonium during three consecutive operations.

drained. Six days later massive gastrointestinal bleeding occurred and a laparotomy was performed. A duodenal ulcer penetrating into the pancreas was found and was considered to be the cause of the psoas abscess. Partial gastrectomy with gastro-jejunostomy was performed. After the operation pyrexia persisted. Leakage of the duodenal stump was suspected and a second laparotomy was performed 7 days after the first. During induction of anaesthesia, the serum potassium concentration increased from 4.40 to a maximum of $6.90 \mathrm{mmol} /$ litre $3 \mathrm{~min}$ after injection of suxamethonium $100 \mathrm{mg}$. A large haematoma in the retroperitoneal space was removed. Pyrexia persisted after that operation. The psoas abscess was drained on two further occasions, 27 and 47 days after the last operation. During induction of anaesthesia on these two occasions, the serum potassium concentration increased from 4.25 to a maximum of $5.90 \mathrm{mmol} /$ litre
$5 \mathrm{~min}$ after injection of suxamethonium, and from 4.30 to $6.00 \mathrm{mmol} /$ litre $4 \mathrm{~min}$ after injection of suxamethonium $100 \mathrm{mg}$ respectively. Subsequently, further retroperitoneal abscesses developed and the patient died 7 months after admission.

\section{Case No. 4}

A 47-year-old man had a long history of chronic pancreatitis, cholelithiasis and stenosis of the common bile duct. Total duodeno-pancreatectomy, cholecystectomy, choledocho-jejunostomy and gastro-jejunostomy were performed. Escherichia coli septicaemia developed after the operation. On the 7 th day after operation a second laparotomy revealed a leakage of the choledocho-jejunal anastomosis, for which a drainage tube was inserted. Pyrexia persisted and large amounts of bile and pus were drained from the abdomen. Two blood cultures were positive for Bacteroides species. Three weeks after the second operation, a laparotomy was performed for a suspected intra-abdominal abscess. During induction of anaesthesia the serum potassium concentration increased from 4.80 to a maximum of $7.55 \mathrm{mmol} /$ litre $3 \mathrm{~min}$ after injection of suxamethonium $100 \mathrm{mg}$. Three thousand millilitre of pus was found between the stomach and the transverse colon. Drainage and transverse colostomy were performed. The patient subsequently improved.

\section{Case No. 5}

A 62-year-old man suffered from plasmocytoma and was receiving chemotherapy and steroids. An operation was performed for a perforated duodenal ulcer, involving excision of the ulcer, vagotomy and gastro-jejunostomy. Pyrexia and peritonitis developed after the operation. A leakage of the anastomosis was suspected and a second laparotomy was performed 4 days after the first. During induction of anaesthesia the serum potassium concentration increased from 4.75 to $4.95 \mathrm{mmol} /$ litre. An accumulation of bilestained fluid was found and drained. A persistent jejunal fistula developed and the patient died 5 weeks later.

\section{Case No. 6}

A 73-year-old man had undergone partial gastrectomy with gastro-duodenostomy. Damage to the common bile duct necessitated choledocho-jejunostomy in a second operation 8 days after the first. Icterus, paralytic ileus, gastrointestinal bleeding, pyrexia and leucocytosis developed after the second 
operation. Drainage of large amounts of fluid from the abdominal cavity suggested a leakage of the anastomosis and a third laparotomy was performed 8 days after the second. During induction of anaesthesia the serum potassium concentration increased from 4.65 to $4.90 \mathrm{mmol} /$ litre. Leakage from both anastomoses and partial pancreatic necrosis were found and gastro-jejunostomy, cholecystostomy and ligation of the common duct were performed. One month later a reconstructive operation was performed and the patient recovered eventually.

\section{Case No. 7}

A 78-year-old man underwent excision of a perforated duodenal ulcer, vagotomy and pyloroplasty. Paralytic ileus, localized right upper abdominal guarding, pyrexia and leucocytosis developed. An intra-abdominal abscess was suspected and a second laparotomy was performed 8 days after the first. The serum potassium concentration increased from 4.40 to $4.70 \mathrm{mmol} /$ litre. Massive distension of the caecum and the ascending colon was found, apparently caused by kinking of the colon at the hepatic flexure. Respiratory insufficiency following surgery necessitated artificial respiration. Septic shock and anuria developed and the patient died 3 days later.

\section{Case No. 8}

A 28-year-old woman suffered abdominal pains, ileus and pyrexia 5 days after a spontaneous delivery of her child. Emergency laparotomy revealed a perforated appendix with generalized peritonitis. The course after surgery was complicated by a right pleural effusion, pyrexia, shivering and leucocytosis. A right subphrenic abscess was suspected and a second laparotomy was performed 5 days after the first. During induction of anaesthesia the serum potassium concentration increased from 4.05 to $4.95 \mathrm{mmol} /$ litre. A right subdiaphragmatic abscess and an abscess in the pouch of Douglas were found. The patient recovered completely following drainage.

\section{Case No. 9}

A 61-year-old man underwent surgery for acute appendicitis. Six days later a second laparotomy was performed because of ileus, caused by adhesions, and a small intra-abdominal abscess. Septic shock, respiratory insufficiency and pyrexia followed. A third laparotomy was performed 4 days after the second; a small bowel fistula was found. Septic lung complications, renal insufficiency, cardiac arrhythmia, pyrexia and leucocytosis continued until several weeks later, when a jejunal fistula was adequately drained from outside by a large drainage tube. After this procedure pulmonary and renal function improved and the signs of infection disappeared. Two weeks later a fourth operation was performed to close the high output fistula. During induction of anaesthesia the serum potassium concentration increased from 4.40 to 5.0 $\mathrm{mmol} /$ litre. The postoperative course was uneventful and the patient recovered completely.

\section{DISCUSSION}

Ketamine causes a small decrease in the serum potassium concentration which is followed by an increase when suxamethonium is given ( $\mathrm{Gal}$ and Malit, 1972). These transient changes are unimportant clinically except for the groups of patients listed in the introduction. This study shows that patients with severe and prolonged intra-abdominal infections represent an additional group susceptible to suxamethoniuminduced hyperkalaemia. The clinical characteristics of our suxamethonium-sensitive patients included catabolism, pyrexia and a leucocytosis. Patient No. 9 fulfilled the above criteria over a long period of time, but when he was finally included in the study his infection had been cured for 10 days. At that time his serum potassium concentration showed no response to suxamethonium.

A relationship between the suxamethoniuminduced hyperkalaemia and the duration of infection suggests a vulnerable period in this group of patients, such as occurs in patients with burns (Schaner et al., 1969), severe trauma (Birch et al., 1969; Mazze, Escue and Houston, 1969), tetanus (Roth and Saidi, 1971) and neuromuscular disease (Cooperman, 1970).

Our series comprises only patients with intraabdominal infections. We do not believe that abscess formation is important and we assume that all longstanding septic conditions may be accompanied by a period of sensitivity to suxamethonium.

In patients susceptible to suxamethonium-induced hyperkalaemia the injection of non-depolarizing muscle relaxants before the administration of suxamethonium has been shown to moderate the potassium response (Weintraub, Heisterkamp and Cooperman, 1969). Our own observations appear to support this measure. Cardiac arrest occurred in the one patient who had not received a previous dose of a non-depolarizing relaxant. All other patients had received an i.v. dose of pancuronium $2 \mathrm{mg} \mathrm{3-5 \textrm {min }}$ before suxamethonium. In those who were suxamethonium-sensitive the serum potassium concentration never exceeded $7.55 \mathrm{mmol} / \mathrm{litre}$ and no cardiac 
or circulatory arrest occurred. A hypothetical mechanism by which non-depolarizing muscle relaxants could prevent damage to the muscle cell membrane is discussed by Waters and Mapleson (1971).

\section{RECOMMENDATIONS}

(1) Patients with severe intra-abdominal or systemic infections lasting longer than 1 week should be considered at risk of suxamethonium-induced hyperkalaemia, and no suxamethonium should be given until the infection has cleared.

(2) When the use of suxamethonium is unavoidable, a non-depolarizing muscle relaxant (pancuronium $1.2-2 \mathrm{mg}$, tubocurarine $6-10 \mathrm{mg}$ or alcuronium 3-5 mg) should be given i.v. 3-5 min before suxamethonium. Resuscitation equipment should be to hand.

(3) External cardiac massage should not be discontinued when defibrillation proves to be ineffective in case of ventricular fibrillation. Defibrillation may be effective only after 10-20 min, when the serum potassium concentration has returned spontaneously to the normal range.

\section{ACKNOWLEDGEMENT}

We are indebted to Miss E. Lorenz, who kindly undertook the laboratory investigations.

\section{REFERENCES}

Birch, A. A., Mitchell, G. D., Playford, G. A., and Lang, C. L. (1969). Changes in serum potassium response to succinylcholine following trauma. f.A.M.A., 210, 490.

Cooperman, L. H. (1970). Succinylcholine-induced hyperkalemia in neuromuscular disease. F.A.M.A., 213, 1867.

Gal, T. J., and Malit, L. A. (1972). The influence of ketamine induction on potassium changes and fasciculations following suxamethonium. Br. F. Anaesth., 44, 1077.

Mazze, R. I., Escue, H. M., and Houston, J. B. (1969). Hyperkalemia and cardiovascular collapse following administration of succinylcholine to the traumatized patient. Anesthesiology, 31, 540.

Roth, F., and Saidi, M. (1971). Gefährlicher Anstieg des Serumkaliums nach Succinylcholin. Anaesthesist, 20, 35.

- Wüthrich, H. (1969). The clinical importance of hyperkalaemia following suxamethonium administration. Br. F. Anaesth., 41, 311.

Schaner, P. J., Brown, R. L., Kirksey, T. D., Gunther, R. C., Ritchie, C. R., and Gronert, G. A. (1969). Succinylcholine-induced hyperkalemia in burned patients. Anesth. Analg. (Cleve.), 48, 764.

Tolmie, J. D., Joyce, T. H., and Mitchell, G. D. (1967). Succinylcholine danger in the burned patient. Anesthesiology, 28, 467.
Walton, J. D., and Farman, J. V. (1973). Suxamethonium hyperkalemia in uraemic neuropathy. Anaesthesia, 28, 666.

Waters, D. J., and Mapleson, W. W. (1971). Suxamethonium pains: hypothesis and observation. Anaesthesia, 26, 127.

Weintraub, H. D., Heisterkamp, D. V., and Cooperman, L. H. (1969). Changes in plasma potassium concentration after depolarizing blockers in anaesthetized man. Br.F. Anaesth., 41, 1048.

\section{HYPERKALIEMIE APRES SUCCINYLCHOLINE DANS LES INFECTIONS INTRA-ABDOMINALES GRAVES}

\author{
RESUME
}

Chez neuf malades opérés pour des complications septiques après intervention abdominale, on a mesuré en permanence le taux sanguin de potassium pendant l'induction de la narcose à l'occasion de la réopération. L'administration de $100 \mathrm{mg}$ de suxamethonium par voie intra-veineuse a été suivie, chez quatre malades, d'une élévation de la kaliémie de 2,5 à $3,1 \mathrm{mmol} /$ litre au dessus de la valeur initiale, dans un délai de 3-6 minutes. Les cinq autres malades n'ont montré aucune modification significative du taux de potassium sanguin. Les quatre malades du premier groupe présentaient un tableau septique et une leucocytose depuis plus de 2 semaines, alors que chez les cinq autres malades la symptomatologie remontait à moins de 9 jours. Il ressort de l'étude que les malades atteints de complications infectieuses intra-abdominales prolongées sont susceptibles de réagir par une hyperkaliémie à l'administration de suxamethonium. Chez ces malades, l'emploi de relaxants musculaires non dépolarisants est seul indiqué. Si l'administration de suxamethonium est impérative, il est recommandé d'injecter au préalable un relaxant musculaire non dépolarisant.

\section{HYPERKALIAEMIE NACH SUCCINYLCHOLIN BEI PATIENTEN MIT SCHWEREN ABDOMINELLEN INFEKTEN}

\section{ZUSAMMENFASSUNG}

Bei neun Patienten mit schweren postoperativen Komplikationen nach abdominellen Eingriffen wurde der Serumkaliumspiegel während der Narkoseeinleitung anlässlich der Revisionsoperation fortlaufend gemessen. Vier Patienten reagierten auf Suxamethonium $100 \mathrm{mg}$ i.v. innerhalb von 3-6 Minuten mit einem Anstieg des Serumkaliums um 2,5-3,1 mmol/liter gegenüber dem Ausgangswert. Bei den vier Patienten, die mit einem Kaliumanstieg reagierten, hatten während mindestens 2 Wochen septische Temperaturen und eine Leukozytose bestanden. Bei den übrigen fünf Patienten waren diese Symptome nicht länger als 9 Tage vorhanden. Aus der Studie geht hervor, dass Patienten mit schweren und langwierigen intra-abdominellen Infektionen eine weitere Patientengruppe darstellen, die mit einer abnormen Kaliumausschüttung auf Suxamethonium reagiert. Diese Patienten sollten nur nicht-depolarisierende Muskelrelaxantien erhalten. Falls eine dringende Indikation für Suxamethonium besteht, wird empfohlen, zuvor ein nicht-depolarisierendes Muskelrelaxans zu injizieren. 


\section{HIPERCALEMIA INDUCIDA POR SUXAMETONIO EN PACIENTES CON SEVERAS INFECCIONES INTRA-ABDOMINALES \\ SUMARIO}

En nueve pacientes sometidos a operaciones repetidas debido a severa infección intra-abdominal consecutiva a cirugía mayor abdominal, se detectaron concentraciones de potasio sérico durante la inducción de anestesia. Cuatro pacientes mostraron un aumento del potasio sérico que iba de 2,5 a $3,1 \mathrm{mmol} / 1$ por encima de los valores basales en 3-6 minutos después de $100 \mathrm{mg}$ de suxametonio (succi- nilcolina) i.v. En cinco pacientes no hubo cambio. Los cuatro pacientes con aumento habían padecido pirexia y leucocitosis durante por lo menos 2 semanas. Los otros cinco habian tenido signos de infección durante un máximo de 9 días. Se concluye que los pacientes con signos de severa infección intra-abdominal de más de 1 semana representan una categoría adicional susceptible de hipercalemia inducida por suxametonio. Debieran recibir solamente miorrelajantes no-despolarizantes. Cuando sea inevitable el uso de suxametonio, se recomienda inyectar antes de su administración un miorrelajante no-despolarizante. 